\author{
Chen-Hsing Lin ${ }^{1}$ \\ Chia-Ming Kuo ${ }^{2}$ \\ Yu-Chih Liu ${ }^{2}$ \\ Hsu-Tun Cheng ${ }^{2}$ \\ Wann-Yin Lin ${ }^{2}$ \\ Jong-Chang $\mathrm{Wu}^{1}$ \\ Li-Fen Wang ${ }^{1}$ \\ Ching-Erh Lin ${ }^{1,2^{*}}$ \\ 1Department of Applied Chemistry, \\ Fooyin University, Ta-Liao, \\ Kao-Hsiung County, Taiwan \\ ${ }^{2}$ Department of Chemistry, \\ National Taiwan University, \\ Taipei, Taiwan
}

Received April 28, 2006

Revised June 8, 2006

Accepted June 8, 2006
Research Article

\section{Enantioselectivity of basic analytes in CZE enantioseparation under reversed-polarity mode using sulfated $\beta$-cyclodextrins as chiral selectors: An unusual temperature effect}

Temperature effects on the enantioselectivity of basic analytes in CZE enantioseparation were studied under reversed-polarity mode using randomly sulfate-substituted $\beta$-CDs (MI-S- $\beta$-CD) as chiral seletors. Two catecholamines (epinephrine and isoproterenol) and two structurally related compounds (octopamine and norephedrine) were selected as test compounds in an electrophoretic system at low $\mathrm{pH}$. The mobility differences between the $(+)$-enantiomers and the (-)-enantiomers of the two catecholamines and dopamine at $40^{\circ} \mathrm{C}$ are greater than those at $25^{\circ} \mathrm{C}$ with $\mathrm{MI}-\mathrm{S}-\beta-\mathrm{CD}$, even at a concentration as low as $0.3 \% \mathrm{w} / \mathrm{v}$. Thus the enantioselectivity of these three basic analytes increases with increasing temperature. This phenomenon results from the inequality of the temperature effect on the mobility of the two enantiomers. In contrast, norephedrine behaves differently. The $(+)$-enantiomers of these basic analytes were found to migrate faster than the $(-)$-enantiomers. Consequently, the unusual temperature effect on the enantioselectivity can be observed when the mobility difference of the $(+)$-enantiomer between 40 and $25^{\circ} \mathrm{C}$ is greater than that of the (-)-enantiomer using MI-S- $\beta$-CD at a concentration greater than about $0.7 \% \mathrm{w} / \mathrm{v}$ for enantioseparation of isoproterenol, $0.4 \% \mathrm{w} / \mathrm{v}$ for epinephrine, and $0.3 \% \mathrm{w} / \mathrm{v}$ for octopamine. This unusual temperature effect offers the advantages to enhance enantioselectivity, to improve enantioseparation, and to reduce migration times.

Keywords: Catecholamines / Enantioselectivity / Enantioseparation / Sulfated $\beta$ cyclodextrins / Temperature effect
DOI 10.1002/elps.200600267

\section{Introduction}

It has been reported that the enantioselectivity in capillary electrophoretic separation decreases by raising the capillary temperature [1-10]. Very recently, an unusual temperature effect on the enantioselectivity of terbutaline and wafarin was reported in which the enantioselectivity was found to increase with increasing temperature [11]. It was suggested that the use of highly sulfated $\beta$-CDs at concentrations greater than the optimum concentration for enantioseparation of basic and neutral analytes should be employed in order to observe this unusual temperature effect [11].

Correspondence: Professor Ching-Erh Lin, Department of Chemistry, National Taiwan University, Taipei, Taiwan 10671

E-mail: celin@ntu.edu.tw

Fax: +886-2-23636359

Abbreviations: MI-S- $\beta$-CD, randomly sulfate-substituted $\beta-C D$; $\mathbf{S I}-$ S- $\beta$-CD, single isomer heptakis(2,3-dihydroxy-6-O-sulfo)- $\beta$-CD
In the course of the study of enantioseparation of catecholamines and structurally related compounds by CZE using randomly sulfate-substituted $\beta-C D$ s (MI-S- $\beta-C D)$ as chiral selectors, the enantioseparation of catecholamines using $\mathrm{Ml}-\mathrm{S}-\beta-\mathrm{CD}$ at $2.0 \% \mathrm{w} / \mathrm{v}$ under reversed-polarity mode at low $\mathrm{pH}$ was significantly improved by raising the capillary temperature [12]. This is because the enantioselectivity of some basic analytes increases with increasing temperature. In this study, the influences of temperature on the enantioselectivity of some basic analytes using sulfated $\beta-C D$ at various concentrations at low $\mathrm{pH}$ under reversed-polarity mode were further investigated systematically. Here we present the results to demonstrate that the unusual temperature effect on the enantioselectivity resulting from the inequality of the temperature effects on the mobility of the two enantiomers can occur even at relatively low concentrations of MI-S- $\beta-C D$.

* Current address: Department of Applied Chemistry, Fooyin University, Ta-Liao, Kao-Hsiung County, Taiwan 831, E-mail: sc030@mail.fy.edu.tw, Fax: +886-7-7826732. 


\section{Materials and methods}

\subsection{Apparatus}

All CE separations were performed on a Beckman P/ACE System $M D Q$, equipped with a photodiode arry detector for absorbance measurements at $200 \mathrm{~nm}$ (Beckman Coulter, Fullerton, CA, USA). Uncoated fused-silica capillaries purchased from Polymicro Technologies (Phoenix, AZ, USA) were used. The dimensions of the capillary were $60.2 \mathrm{~cm} \times 50 \mu \mathrm{m}$ id. The effective length of the capillary was $50 \mathrm{~cm}$ from the injection end of the capillary. The CE system was interfaced with a microcomputer. System Gold software of Beckman was used for data acquisition. For $\mathrm{pH}$ measurements, a pH meter (Suntex Model SP701, Taipei, Taiwan) was employed with a precision of $\pm 0.01 \mathrm{pH}$ unit.

\subsection{Chemicals and reagents}

Epinephrine, octopamine, and ( \pm )- and (-)-isoproterenol hydrocholoride were obtained from Sigma (St. Louis, MO, USA). Norephedrine hydrochloride and MI-S- $\beta-C D$ were obtained from Sigma-Aldrich. The single isomer heptakis (2,3-dihydroxy-6-O-sulfo)- $\beta$-CD (SI-S- $\beta$-CD) was purchased from Antek Instruments (Houston, TX, USA). All other chemicals were of analytical grade. Deionized water was prepared with a Milli-Q system (Millipore, Bedford, MA. USA).

Standard solutions of the analytes, with the exception of norephedrine, at a concentration of $20 \mu \mathrm{g} / \mathrm{mL}$ were prepared by dissolving analytes in an aqueous solution. The sample solution of norephedrine at a concentration of $50 \mu \mathrm{g} / \mathrm{mL}$ was employed. The $\mathrm{pH}$ of a phosphate buffer was adjusted to the desired $\mathrm{pH}$ value by mixing various proportions of a certain concentration of sodium dihydrogenphosphate solution with the same concentration of phosphoric acid. All buffer solutions, freshly prepared weekly and stored in a refrigerator before use, were filtered through a membrane filter $(0.22 \mu \mathrm{m})$.

\subsection{Electrophoretic procedure}

When a new capillary was used, the capillary was washed for 30 min with $1.0 \mathrm{M} \mathrm{NaOH}$ solution followed by $30 \mathrm{~min}$ washing with deionized water at $25^{\circ} \mathrm{C}$. Before each injection, the capillary was prewashed for 3 min with running buffer and postwashed for $3 \mathrm{~min}$ with deionized water, 3 min with $0.1 \mathrm{M} \mathrm{NaOH}$, and 5 min with deionized water to maintain proper reproducibility of run-to-run injections. Sample injections were done in a hydrodynamic mode over $5 \mathrm{~s}$ under a pressure of $1.0 \mathrm{psi}$ at $25^{\circ} \mathrm{C}$. The meas- urements were run at least in triplicate to ensure reproducibility. An applied voltage of either $+20 \mathrm{kV}$ (in the normal polarity mode) or $-20 \mathrm{kV}$ (in the reversed-polarity mode) for phosphate buffer was selected to keep the total current less than $100 \mu \mathrm{A}$. The detection wavelength was set at $200 \mathrm{~nm}$ (pH 3.0). Peak identification was conducted by spiking with the analyte to be identified. Mesityl oxide was used as neutral marker.

\subsection{Mobility calculations}

The apparent mobility of analytes was calculated from the observed migration times using the equation

$\mu=\frac{L_{d} L_{t}}{V t_{m}}$

where $\mu$ is the apparent mobility, $t_{\mathrm{m}}$ is the migration time measured directly from the electropherogram, $L_{t}$ is the total length of capillary, $L_{d}$ is the length of capillary between injection and detection, and $V$ is the applied voltage.

The enantioselectivity $(\alpha)$ of basic analytes was calculated with the equation

$\alpha=\frac{\mu^{(+)}}{\mu^{(-)}}$

where the superscripts $(+)$ and $(-)$ refer to the $(+)$ - and (-)-enantiomers, respectively.

\section{Results and discussion}

The structures of two catecholamines and two structurally related compounds, together with their $\mathrm{p} K_{\mathrm{a}}$ values, are given in Table 1. At low $\mathrm{pH}$, these compounds are protonated and thus exist as basic analytes. As sulfated $\beta-C D$ used is a mixture composed of a number of MI-S- $\beta$ $\mathrm{CD}$ (typically with substitution $7-11 \mathrm{~mol} / \mathrm{mol} \beta-C D$ ), the concentration of this type of sulfated $\beta-C D$ is given in $\% \mathrm{w} / \mathrm{v}$ instead of $\mathrm{mM}$. Figure 1 shows the electropherograms of isoproterenol obtained at 25 and $40^{\circ} \mathrm{C}$ using a phosphate buffer $(50 \mathrm{mM})$ containing MI-S- $\beta-C D$ at various concentrations at $\mathrm{pH}$ 3.0. The second eluted enantiomer was confirmed as the $(-)$-enantiomer by spiking. Thus the (+)-enantiomer migrated faster (toward the anode) than the (-)-enantiomer. As was observed for terbutaline [11], the two enantiomers of isoproterenol migrated more rapidly and the difference in the migration times between the two enantiomers became lesser when the concentration of $\mathrm{MI}-\mathrm{S}-\beta-\mathrm{CD}$ increased from 0.3 to $2.0 \% \mathrm{w} / \mathrm{v}$. Moreover, the enantiomeric peaks became broader and the peak shape became more fronted as the concentration of MI-S- $\beta$-CD decreased from 0.5 to $0.3 \% \mathrm{w} / \mathrm{v}$. With MI-S- $\beta-\mathrm{CD}$ at relatively low concentra- 
Table 1. $p K_{\mathrm{a}}$ values and structures of catecholamines and structurally related compounds studied

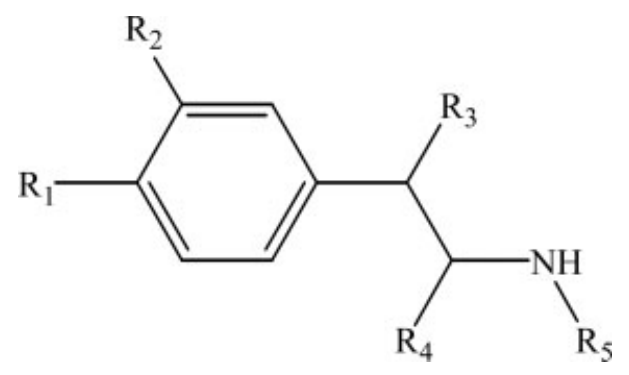

\begin{tabular}{lllllll}
\hline Basic analytes & $\mathrm{pK}_{\mathrm{a}}^{\mathrm{a}}$ & $R_{1}$ & $\mathrm{R}_{2}$ & $\mathrm{R}_{3}$ & $\mathrm{R}_{4}$ & $\mathrm{R}_{5}$ \\
\hline Epinephrine & 8.58 & $\mathrm{OH}$ & $\mathrm{OH}$ & $\mathrm{OH}$ & $\mathrm{H}$ & $\mathrm{CH}_{3}$ \\
& 8.78 & & & & & \\
& 10.0 & & & & & \\
Isoproterenol & 8.60 & $\mathrm{OH}$ & $\mathrm{OH}$ & $\mathrm{OH}$ & $\mathrm{H}$ & $\mathrm{CH}\left(\mathrm{CH}_{3}\right)_{2}$ \\
& 10.1 & & & & & \\
& 12.0 & & & & & \\
Octopamine & 8.88 & $\mathrm{OH}$ & $\mathrm{H}$ & $\mathrm{OH}$ & $\mathrm{H}$ & $\mathrm{H}$ \\
& 9.53 & & & & & \\
Norephedrine & & $\mathrm{H}$ & $\mathrm{H}$ & $\mathrm{OH}$ & $\mathrm{CH}_{3}$ & $\mathrm{H}$ \\
\hline
\end{tabular}

a) See [15].

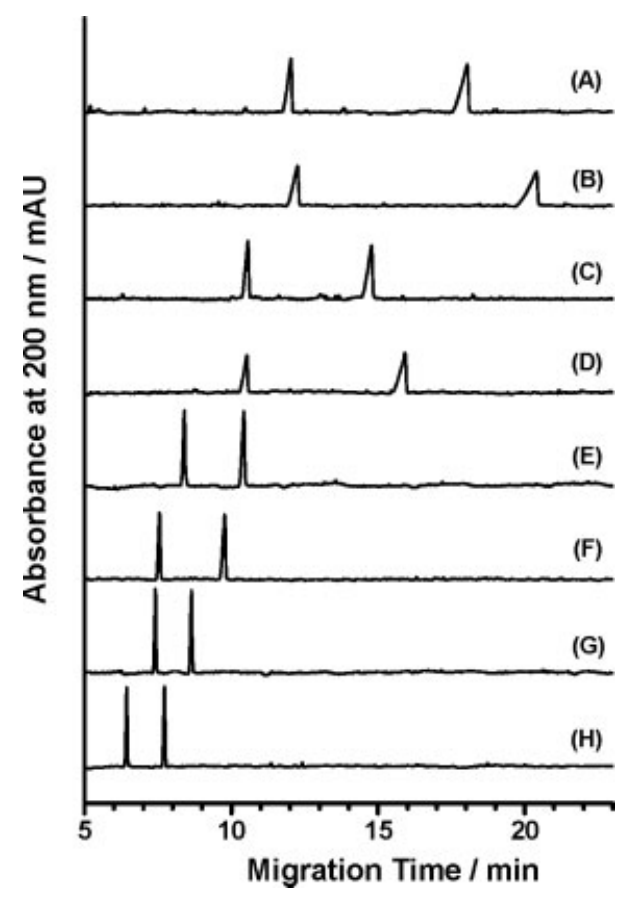

Figure 1. Electropherograms of isoproterenol obtained using $\mathrm{Ml}-\mathrm{S}-\beta-\mathrm{CD}$ at various concentrations at 25 and $40^{\circ} \mathrm{C}$. (A) $0.3 \% \mathrm{w} / \mathrm{v}, 25^{\circ} \mathrm{C}$; (B) $0.3 \% \mathrm{w} / \mathrm{v}, 40^{\circ} \mathrm{C}$; (C) $0.5 \% \mathrm{w} /$ v, $25^{\circ} \mathrm{C}$; (D) $0.5 \% \mathrm{w} / \mathrm{v}, 40^{\circ} \mathrm{C}$; (E) $1.0 \% \mathrm{w} / \mathrm{v}, 25^{\circ} \mathrm{C}$; (F) $1.0 \%$ $\mathrm{w} / \mathrm{v}, 40^{\circ} \mathrm{C}$; (G) $2.0 \% \mathrm{w} / \mathrm{v}, 25^{\circ} \mathrm{C}$; (H) $2.0 \% \mathrm{w} / \mathrm{v}, 40^{\circ} \mathrm{C}$. tions, the $(+)$ - and (-)-enantiomers were found to migrate more slowly at 40 than at $25^{\circ} \mathrm{C}$ (Figs. $1 \mathrm{~A}$ and $\mathrm{B}$ ). However, using $\mathrm{MI}-\mathrm{S}-\beta-\mathrm{CD}$ at higher concentrations $(>1.0 \% \mathrm{w} / \mathrm{v})$, the $(+)$ - and $(-)$-enantiomers migrated faster at 40 than at $25^{\circ} \mathrm{C}$ (Figs. $1 \mathrm{C}$ and $\left.\mathrm{D}\right)$.

Figure 2 shows the variations of the apparent mobility as a function of MI-S- $\beta$-CD concentration for the two enantiomers of isoproterenol at 25 and $40^{\circ} \mathrm{C}$. It is interesting to note that the mobility differences between the $(+)$-enantiomers and the (-)-enantiomers of the two catecholamines and octopamine at $40^{\circ} \mathrm{C}$ are greater than those at $25^{\circ} \mathrm{C}$ with MI-S- $\beta-\mathrm{CD}$, even at a concentration as low as $0.3 \% \mathrm{w} / \mathrm{v}$. With the use of MI-S- $\beta-C D$ at a concentration greater than about $0.7 \% \mathrm{w} / \mathrm{v}$, the mobility difference of the $(+)$-enantiomer between 40 and $25^{\circ} \mathrm{C}$ was found to be greater than that of the (-)-enantiomer. On the other hand, with the use of MI-S- $\beta$-CD at a concentration less than about $0.7 \% \mathrm{w} / \mathrm{v}$, the mobility difference of the $(-)$ enantiomer between 40 and $25^{\circ} \mathrm{C}$ was found to be greater than that of the $(+)$-enantiomer. Consequently, the enantioselectivity increases with increasing temperature. It is noted that this unusual temperature effect on the enantioselectivity can be observed even at a concentration as low as $0.3 \% \mathrm{w} / \mathrm{v}$, which is approximately the lowest detection concentration within a reasonable analysis time for enantioseparation of isoproterenol with MI-S- $\beta-C D$ under reversed-polarity mode. Obviously, the temperature effects on the mobility of the two enantiomers are not

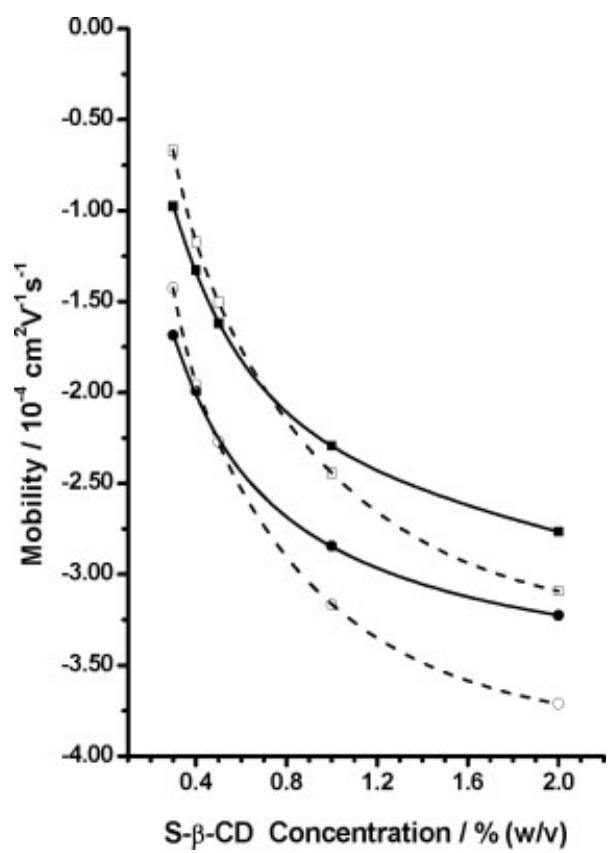

Figure 2. Variations of the apparent mobility of the two enantiomers of isoproterenol as a function of MI-S- $\beta-C D$ concentration in the range $0.3-2.0 \% \mathrm{w} / \mathrm{v}$ : $(+)$-enantiomer at $25^{\circ} \mathrm{C}(\mathbf{O})$; (-)-enantiomer at $25^{\circ} \mathrm{C}(\square) ;(+)$-enantiomer at $40^{\circ} \mathrm{C}(\bigcirc)$; (-)-enantiomer at $40^{\circ} \mathrm{C}(\square)$. 
equal. As the binding constants of basic analytes to MI-S$\beta-C D$ decrease with increasing temperature $[13,14]$, the results of the unusual temperature effect may reveal that the limiting electrophoretic mobility of the (+)-enantiomers at higher temperatures increases to a greater extent than that of the (-)-enantiomers. In other words, the inequality of the temperature effects on the mobility of the two enantiomers determines whether the enantioselectivity of basic analytes increases or decreases with increasing temperature.

Figure 3 shows the variations of the enantioselectivity of isoproterenol as a function of MI-S- $\beta-C D$ concentration at 25 and $40^{\circ} \mathrm{C}$. The results clearly demonstrate that the enantioselectivity of isoproterenol increases with increasing temperature using $\mathrm{MI}-\mathrm{S}-\beta-\mathrm{CD}$ in the concentration range $0.3-2.0 \% \mathrm{w} / \mathrm{v}$ under reversed-polarity mode. As shown in Fig. 3, no crossing of the two enantioselectivity curves at 25 and $40^{\circ} \mathrm{C}$ occurs in this concentration range. As this unusual temperature effect on the enantioselectivity can be observed even at relatively low concentrations of MI-S- $\beta-C D$, the suggestion given by Westall et al. [11] that the use of MI-S- $\beta-C D$ at concentrations above the optimum concentration for enantioseparation is not necessary to observe the unusual temperature effect on enantioselectivity.

In order to add more support, epinephrine and two structurally related compounds (octopamine and norephedrine) are also included in this study. Figures 4, 5 show

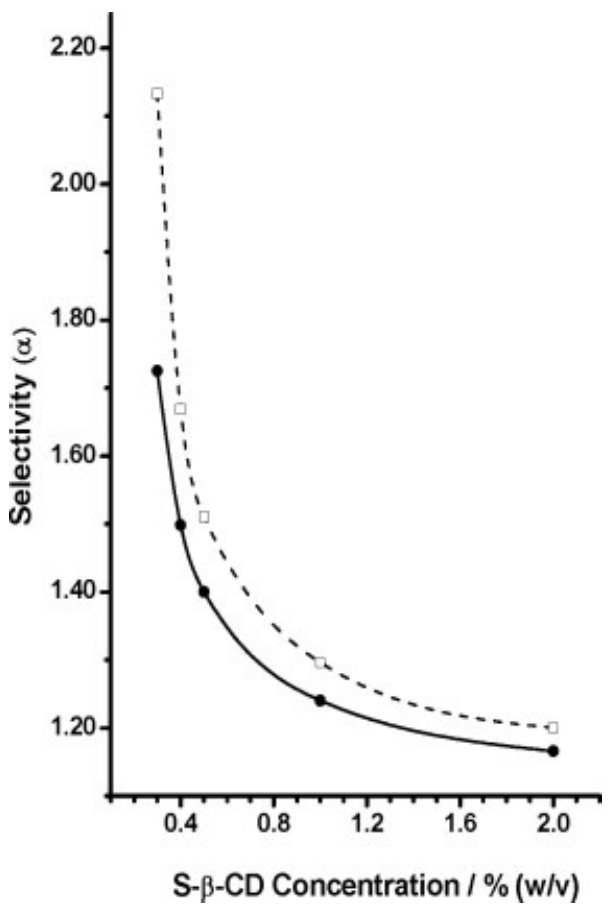

Figure 3. Variations of the enantioselectivity of isoproterenol as a function of MI-S- $\beta$-CD concentration at $25^{\circ} \mathrm{C}(\bullet)$ and at $40^{\circ} \mathrm{C}(\square)$.

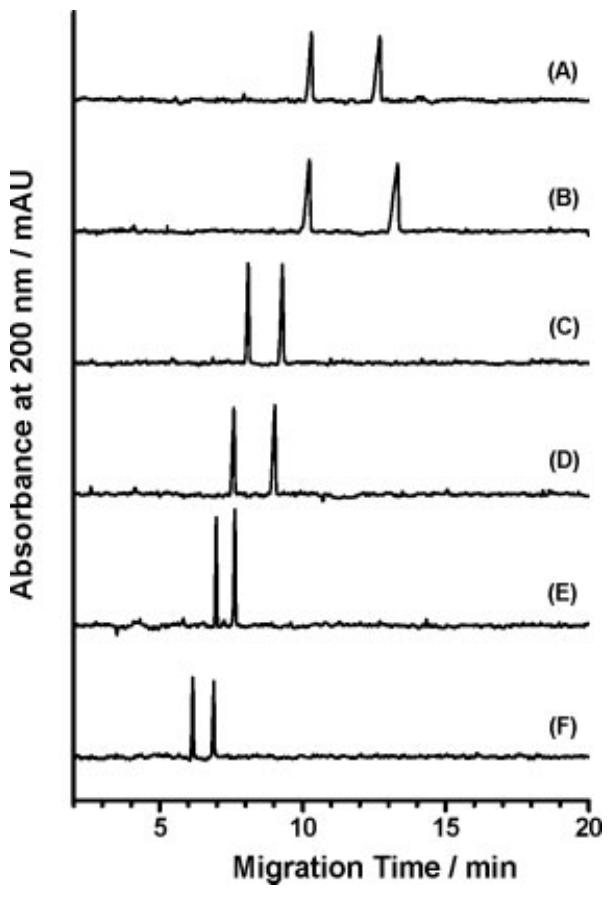

Figure 4. Electropherograms of epinephrine obtained using MI-S- $\beta-C D$ at various concentrations at 25 and $40^{\circ} \mathrm{C}$. (A) $0.3 \% \mathrm{w} / \mathrm{v}, 25^{\circ} \mathrm{C}$; (B) $0.3 \% \mathrm{w} / \mathrm{v}, 40^{\circ} \mathrm{C}$; (C) $1.0 \% \mathrm{w} /$ $\mathrm{v}, 25^{\circ} \mathrm{C}$; (D) $1.0 \% \mathrm{w} / \mathrm{v}, 40^{\circ} \mathrm{C}$; (E) $2.0 \% \mathrm{w} / \mathrm{v}, 25^{\circ} \mathrm{C}$; (F) $2.0 \%$ $\mathrm{w} / \mathrm{v}, 40^{\circ} \mathrm{C}$.

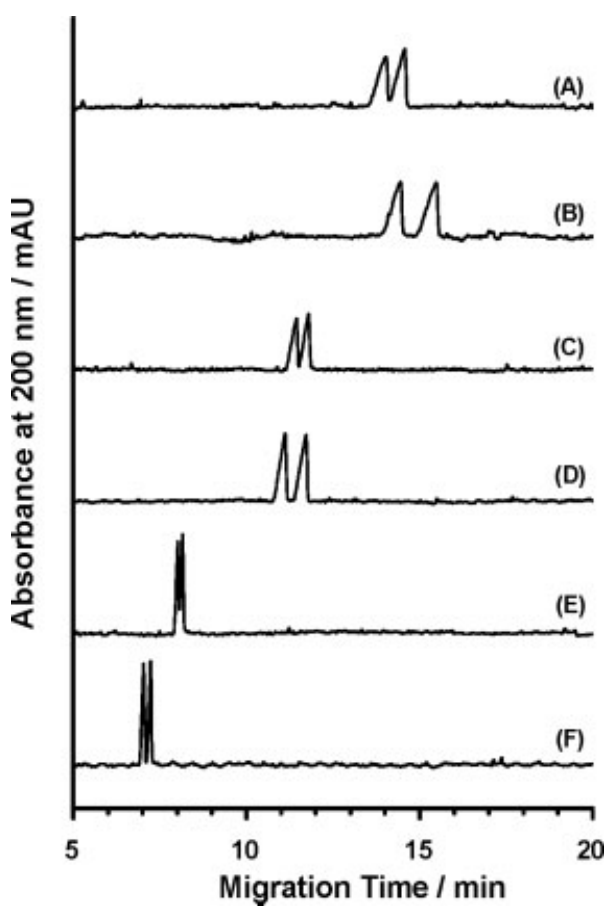

Figure 5. Electropherograms of octopamine obtained using $\mathrm{Ml}-\mathrm{S}-\beta-\mathrm{CD}$ at various concentrations at 25 and $40^{\circ} \mathrm{C}$. (A) $0.3 \% \mathrm{w} / \mathrm{v}, 25^{\circ} \mathrm{C}$; (B) $0.3 \% \mathrm{w} / \mathrm{v}, 40^{\circ} \mathrm{C}$; (C) $1.0 \% \mathrm{w} /$ $\mathrm{v}, 25^{\circ} \mathrm{C}$; (D) $1.0 \% \mathrm{w} / \mathrm{v}, 40^{\circ} \mathrm{C}$; (E) $2.0 \% \mathrm{w} / \mathrm{v}, 25^{\circ} \mathrm{C}$; (F) $2.0 \%$ $\mathrm{w} / \mathrm{v}, 40^{\circ} \mathrm{C}$. 


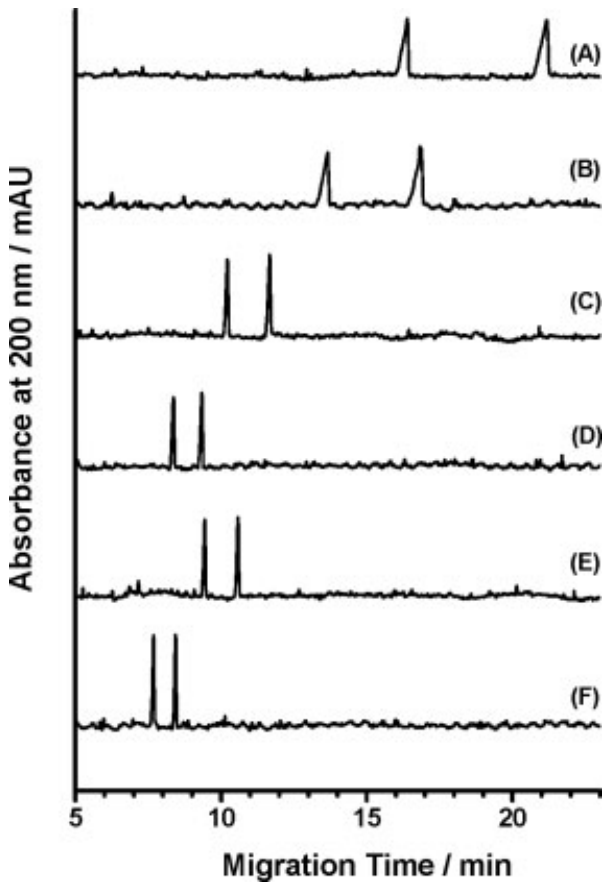

Figure 6. Electropherograms of norephedrine obtained using $\mathrm{MI}-\mathrm{S}-\beta-\mathrm{CD}$ at various concentrations at 25 and $40^{\circ} \mathrm{C}$. (A) $0.6 \% \mathrm{w} / \mathrm{v}, 25^{\circ} \mathrm{C}$; (B) $0.6 \% \mathrm{w} / \mathrm{v}, 40^{\circ} \mathrm{C}$; (C) $1.5 \% \mathrm{w} /$ $\mathrm{v}, 25^{\circ} \mathrm{C}$; (D) $1.5 \% \mathrm{w} / \mathrm{v}, 40^{\circ} \mathrm{C}$; (E) $2.0 \% \mathrm{w} / \mathrm{v}, 25^{\circ} \mathrm{C}$; (F) $2.0 \%$ $\mathrm{w} / \mathrm{v}, 40^{\circ} \mathrm{C}$.

some electropherograms of epinephrine and octopamine obtained, respectively, using MI-S- $\beta-\mathrm{CD}$ at $0.3,1.0$, and $2.0 \% \mathrm{w} / \mathrm{v}$ at 25 and $40^{\circ} \mathrm{C}$. The trends in the variations of the apparent mobility of the two enantiomers of both epinephrine and octopamine as a function of MI-S- $\beta-C D$ concentration at 25 and $40^{\circ} \mathrm{C}$ are similar to those of isoproterenol shown in Fig. 2. The variations of the enantioselectivity of both epinephrine and octopamine as a function of MI-S- $\beta-\mathrm{CD}$ concentration at $25^{\circ}$ and $40^{\circ} \mathrm{C}$ are also similar to those of isoproterenol shown in Fig. 3, but to a less extent. Figure 6 shows some electropherograms of norephedrine obtained using MI-S- $\beta-\mathrm{CD}$ at $0.6,1.5$, and $2.0 \% \mathrm{w} / \mathrm{v}$ at 25 and $40^{\circ} \mathrm{C}$. On the contrary, norephedrine exhibits normal temperature effect on enantioselectivity when capillary temperature is raised from 25 to $40^{\circ} \mathrm{C}$.

The mobility and enantioselectivity data obtained for the test compounds using 0.5 and $2.0 \% \mathrm{w} / \mathrm{v}$ MI-S- $\beta-C D$ at 25 and $40^{\circ} \mathrm{C}$, are given in Table 2 . The results clearly indicate that the enantioselectivities of epinephrine, isoproterenol, and octopamine at $40^{\circ} \mathrm{C}$ are greater than those at $25^{\circ} \mathrm{C}$, whereas the enantioselectivity of norephedrine at $40^{\circ} \mathrm{C}$ is smaller than that at $25^{\circ} \mathrm{C}$. Table 3 gives the mobility differences of the two enantiomers of test compounds between 40 and $25^{\circ} \mathrm{C}$ using MI-S- $\beta-C D$ at $0.4,1.0$, and $2.0 \% \mathrm{w} / \mathrm{v}$. As the (+)-enantiomers of these basic analytes migrate before the (-)-enantiomers, the fact that the mobilities of the (+)-enantiomers of epinephrine, isoproterenol, and octopamine at higher temperatures increase to a greater extent than those of the corresponding (-)-enantiomers with MI-S- $\beta-C D$ at 1 and $2 \% \mathrm{w} / \mathrm{v}$ demonstrates affirmatively that the enantioselectivity of these three basic analytes increases with increasing temperature. Moreover, as indicated in Table 3 using $\mathrm{MI}-\mathrm{S}-\beta-\mathrm{CD}$ at $0.4 \% \mathrm{w} / \mathrm{v}$, the negative values of the mobility difference obtained for the two enantiomers of isoproterenol mean that both (+)- and (-)-enantiomers at $40^{\circ} \mathrm{C}$ migrated more slowly than their corresponding enantiomers at $25^{\circ} \mathrm{C}$. As the mobility difference of the $(-)$-enantiomer of isoproterenol between 40 and $25^{\circ} \mathrm{C}$ is greater than that of the (+)-enantiomer, the enantioselectivity of isoproterenol is affirmatively confirmed to increase with increasing temperature.

Table 2. Apparent mobility and enantioselectivity data of test compounds at 25 and $40^{\circ} \mathrm{C}$ using $\mathrm{MI}-\mathrm{S}-\beta-\mathrm{CD}$ at 0.5 and $2.0 \% \mathrm{w} / \mathrm{v}$

\begin{tabular}{|c|c|c|c|c|c|c|}
\hline \multirow[t]{2}{*}{ Basic analytes } & $\underline{\mu_{25^{\circ} \mathrm{C}}^{(+)}}$ & $\mu_{25^{\circ} \mathrm{C}}^{(-)}$ & $\alpha_{25^{\circ} \mathrm{C}}$ & $\mu_{40^{\circ} \mathrm{C}}^{(+)}$ & $\mu_{40^{\circ} \mathrm{C}}^{(-)}$ & $\alpha_{40^{\circ} \mathrm{C}}$ \\
\hline & \multicolumn{3}{|c|}{$0.5 \%$ w/v MI-S- $\beta-C D$} & \multicolumn{3}{|c|}{$0.5 \% \mathrm{w} / \mathrm{v} \mathrm{MI}-\mathrm{S}-\beta-\mathrm{CD}$} \\
\hline Epinephrine & 2.95 & 2.57 & 1.15 & 3.14 & 2.64 & 1.19 \\
\hline Isoproterenol & 2.27 & 1.62 & 1.40 & 2.27 & 1.50 & 1.51 \\
\hline Octopamine & 2.29 & 2.24 & 1.03 & 2.48 & 2.38 & 1.05 \\
\hline \multirow[t]{2}{*}{ Norephedrine } & 1.05 & 0.70 & 1.50 & 1.20 & 0.84 & 1.42 \\
\hline & \multicolumn{3}{|c|}{$2.0 \% \mathrm{w} / \mathrm{v} \mathrm{MI}-\mathrm{S}-\beta-\mathrm{CD}$} & \multicolumn{3}{|c|}{$2.0 \% \mathrm{w} / \mathrm{v} \mathrm{MI}-\mathrm{S}-\beta-\mathrm{CD}$} \\
\hline Epinephrine & 3.66 & 3.42 & 1.07 & 4.29 & 3.95 & 1.09 \\
\hline Isoproterenol & 3.23 & 2.77 & 1.17 & 3.71 & 3.09 & 1.20 \\
\hline Octopamine & 3.29 & 3.24 & 1.01 & 3.94 & 3.86 & 1.02 \\
\hline Norephedrine & 2.53 & 2.25 & 1.13 & 3.11 & 2.83 & 1.10 \\
\hline
\end{tabular}


Table 3. Mobility differences of the two enantiomers between 40 and $25^{\circ} \mathrm{C}$ using $\mathrm{MI}-\mathrm{S}-\beta-\mathrm{CD}$ at various concentrations

\begin{tabular}{|c|c|c|c|c|c|c|c|}
\hline \multirow[t]{2}{*}{ Basic analytes } & \multicolumn{2}{|c|}{$0.4 \% \mathrm{w} / \mathrm{v}$ MI-S- $\beta-\mathrm{CD}$} & \multicolumn{2}{|c|}{$1.0 \% \mathrm{w} / \mathrm{v} \mathrm{MI}-\mathrm{S}-\beta-\mathrm{CD}$} & \multicolumn{2}{|c|}{$2.0 \% \mathrm{w} / \mathrm{v}$ MI-S- $\beta-\mathrm{CD}$} & \multirow{2}{*}{$\begin{array}{l}\text { Enantio } \\
\text { selectivity }\end{array}$} \\
\hline & $\Delta \mu^{(+)}$ & $\Delta \mu^{(-)}$ & $\Delta \mu^{(+)}$ & $\Delta \mu^{(-)}$ & $\Delta \mu^{(+)}$ & $\Delta \mu^{(-)}$ & \\
\hline Epinephrine & +0.05 & -0.37 & +0.46 & +0.34 & +0.63 & +0.53 & Increase \\
\hline Isoproterenol & -0.03 & -0.34 & +0.33 & +0.15 & +0.48 & +0.32 & Increase \\
\hline Octopamine & +0.06 & +0.01 & +0.42 & +0.37 & +0.65 & +0.62 & Increase \\
\hline Norephedrine & - & - & +0.38 & +0.38 & +0.58 & +0.58 & Decrease \\
\hline
\end{tabular}

It is wort to note that the increased enantioselectivity with increasing temperature cannot be observed for enantioseparation of isoproterenol, epinephrine, and octopamine using MI-S- $\beta-C D$ under normal polarity mode. Also, this unusual temperature effect on enantioselectivity of catecholamines cannot be observed using the SI-S- $\beta$-CD at moderate to high concentrations under normal polarity mode because the bindings of catecholamines with SI-S$\beta-C D$ are comparatively much weaker than those with MIS- $\beta-C D$.

\section{Concluding remarks}

The results of this study indicate that the enantioselectivity increases upon increasing the temperature on using MI-S- $\beta$-CD as chiral selectors for enantioseparation of isoproterenol, epinephrine, and octopamine under reversed-polarity mode. The unusual temperature effect on the enantioselectivity results from the inequality of the temperature effects on the mobility of the two enantiomers. The mobility differences of the $(+)$-enantiomers between 40 and $25^{\circ} \mathrm{C}$ are greater than those of the (-)enantiomers using MI-S- $\beta$-CD at a concentration greater than $0.7,0.4$, and $0.3 \% \mathrm{w} / \mathrm{v}$ for enantioseparation of isoproterenol, epinephrine, and octopamine, respectively. Consequently, the enantioselectivity can be enhanced and enantioseparation can be improved by raising the capillary temperature.

We gratefully acknowledge the National Science Council of the ROC (Taiwan) for financial support.

\section{References}

[1] Schutzner, W., Fanali, S., Electrophoresis 1992, 13, 687690.

[2] Heuermann, M., Blaschke, G., J. Chromatogr. 1993, 648, 267-274.

[3] Rawjee, Y. Y., Starek, D. U., Vigh, G., J. Chromatogr. 1993, 635, 291-306.

[4] Nishi, H., Kokusenya, Y., Miyamoto, T., Sato, T., J. Chromatogr. A 1994, 659, 449-457.

[5] Fanali, S., Flieger, M., Steinerova, N., Nardi, A., Electrophoresis 1994, 13, 39-43.

[6] Reijenga, J. C., Ingelse, B. A., Everaerts, F. M., J. Chromatogr. A 1997, 792, 371-378.

[7] Yuan, H., Thompson, R. A., Ellison, D. K., J. Liq. Chromatogr. Rel. Technol. 2002, 25, 2999-3015.

[8] Foulon, C., Danel, C., Vaccher, M.-P., Bonte, J.-P. et al., Electrophoresis 2004, 25, 2735-2744.

[9] Morante-Zarcero, S., Crego, A. L., Sierra, I., Fajardo, M., Marina, M. L., Electrophoresis 2004, 25, 2745-2754.

[10] Zhuo, L., Thompson, R., Ellison, D., Wyvratt, J. M., Electrophoresis 2004, 25, 2860-2865.

[11] Westall, A., Malmstrom, T., Peterson, P., Electrophoresis 2006, 27, 859-864.

[12] Lin, C. E., Cheng, H. T., Fang, I. J., Liu, Y. C. et al., Electrophoresis 2006, 27, 3443-3451.

[13] Altria, K. D., Goodall, D. M., Rogan, M. M., Chromatographia 1992, 34, 19-24.

[14] Shibukawa, A., Lloyd, D. K., Wainer, I. W., Chromatographia 1993, 35, 419-429.

[15] Drayton, C. J., Comprehensive Medical Chemistry, Pergamon Press, Oxford, UK 1990, Vol. 6. 